\title{
ECONOMIC SECURITY AS AN ELEMENT OF STRATEGIC MANAGEMENT SYSTEM: ACCOUNTING AND ANALYTICAL ASPECT
}

\author{
Larysa Tytenko' \\ University of the State Fiscal Service of Ukraine, Ukraine
}

\begin{abstract}
The purpose of the paper is to implement the strategic management system at an enterprise, many information resources are required. Being at the crossroads of accounting, analysis, control, and coordination, the accounting and analytical support plays a special role in the enterprise's strategic management - it connects, integrates, and coordinates all these functions, transferring the enterprise management to a qualitatively new level. Methodology. The accounting and analytical support serves as a self-regulation mechanism at the enterprise providing feedback in the management system. The effectiveness of strategic management is measured by the enterprise response to changes in the environment, by time limits of data flow. The data flow speed is determined by the maximum amount of information received for the shortest period of time and indicates the economic system efficiency, ability to respond flexibly, timely, and adequately to changes in the external and internal environment. The enterprise management effectiveness depends on the enterprise managers' knowledge of the market, the conditions of its operation, the number of competitors, similar goods, development dynamics, etc. The purpose of the article is to justify expediency of the logistic approach applied to the organization of the enterprise's accounting and analytical support, harmonization of principles of its development, determination of an element for analysis of the necessary information about the enterprise resources, competition, and changes in the internal and external environment. Results. To achieve this goal, an issue of an integrated approach to the creation of the accounting and analytical support as a key tool for the formation of a data flow in the enterprise's strategic development system was considered. Theoretical approaches to the definition of "accounting and analytical support" are generalized and the main directions of the accounting and analytical support development, which can be used at modern enterprises, are described herein. The accounting and analytical support is proved to be a continuous data flow aimed at a single goal - to provide complete, reliable, relevant information on all levels of management in different activities. Specific characteristics of data flows (purposefulness, speed, discreteness, intensity, capacity, multifunctionality) are proved to increase the accounting and analytical support efficiency. Practical implications. All flow processes at an enterprise form an information system, consisting of: 1) information infrastructure (information and technology); 2) information support (means of information collection, processing, storage and transmission - information and communication resources). The data flow is believed to be one of the elements in the information space, which is considered from different aspects. For this purpose, the accounting and analytical support was offered to form on the principles of the logistic approach. Elements of the accounting and analytical support system are proposed to harmonize on modern principles, grouped in three directions: from general scientific principles of development strategy formation to development of requirements for the information support quality. Also, a key component is revealed to be required to coordinate and assess the entire system efficiency. Value/originality. The economic security system was proposed as this component, and the directions for the accounting and analytical support for economic security under strategic development were explored. The sequence of information formation and control measures in the economic security system is determined herein.
\end{abstract}

Key words: strategic management, accounting and analytical system, economic security, principles, methods, analysis, information, control, information flow, information flow management.

JEL Classification: M10, M41, P5

\footnotetext{
Corresponding author:

${ }^{1}$ Department of Accounting and Analytical Knowledge Bases, University of the State Fiscal Service of Ukraine.

E-mail: tytenkolv@gmail.com
} 


\section{Introduction}

Significant changes in the environment and quickly growing information volume, which should be considered when making management decisions, result in the continuous development of the theory and practice of enterprise management. Currently, information became one of the valuable resources along with traditional material ones, so its processing and the transformation can be accepted as one of the modern technologies like transformation of material resources. The processing information scope, methods, and means reached a level when information became a product and one of the most important strategic resources of the enterprise. An assessment and analysis of information about the enterprise's external and internal environment, opportunities and competitive advantages, are considered to be a basis not only for the approval of individual management decisions but also for the creation of conditions for systematic management of the enterprise's production and economic activities, and the enterprise's development rate and efficiency directly depend on its ability to process ever-increasing amount of information flows.

Today, the strategic management concept seems to be very popular, aimed at ensuring development, increasing the enterprise's cost and competitiveness in a changing environment, considering the time factor. By its nature, strategic management is aimed at predicting global changes in the enterprise's external and internal environment and the search for strategies to ensure long-term and effective development in the future. However, the strategic management effectiveness directly depends on the compliance of the enterprise's information support with the modern management information needs. The accounting system is traditionally considered to be the most developed information subsystem of the enterprise. So, according to Kuzhelny M.V. and Linnyk V.G. (2001), accounting is the basis of information support -up to $80 \%$ of the total volume of information is formed up in its system. However, today it is impossible to meet users' needs only basing on retrospective information obtained through the continuous recording of business transactions in the accounting system. This is due to several significant reasons: accounting does not involve non-financial information and information on the environmental impact on accounting objects; accounting does not include information about the market value of assets and liabilities. Thus, in order to implement the strategic management process, the enterprise's information support should be definitely improved to create economically favourable conditions for long-term operation of the enterprise, with the possibility to minimize threatening effects of the external environment and to form significant competitive advantages. That is, to create long-term economically safe operating conditions. Thus, the issues of improving the information basis for making strategic decisions and, first of all, one of its key elements - accounting and analytical support, are considered to be urgent.

The purpose of this paper is to justify application of the logistic approach to the organization of the enterprise's accounting and analytical support, determination of principles of its development, determination of an element allowing the necessary information about the enterprise's resources, competitive position, and changes in the internal and external environment.

\section{Results and discussions}

The dialectic method and systematic approach to the concept analysis are used during the studying; systematic, comparative method of observation, graphical method - to study principles of interaction between the elements of the accounting and analytical support system and the economic security system.

Strategic development is quite a wide concept, disclosed differently for each enterprise, depending on activity, sectoral features, etc. However, always strategic development is provided by combining management efforts in different areas, such as management competitiveness, resource and cost management, research and development, pricing management, etc. But in any case, the necessity to form and maintain an information system able to provide fast adaptation of the business entity to changing conditions of the economic environment is considered to be an integral part of the strategic management implementation into the enterprise's activities. At the same time, the information system should contain a subsystem to guarantee, first of all, the strategic development security.

Therefore, such an integral part of the information system as accounting and analytical support is essential for the effective functioning of the management mechanism.

According to many scientists, the "information support" concept is broader comparing to the "accounting and analytical support" concept because it includes all the information used in the management system, and information technologies, hardware and software, while accounting and analytical support is the accounting and analysis system, designed to systematize information, to coordinate enterprise development directions, to assess the effectiveness of management decisions.

Many views on the interpretation of the "accounting and analytical support" term have been formed in the current economic literature (Table 1).

Summing up the scientists' opinions, we can note that in most cases accounting and analytical support is considered as a system (Holova S.F., Shtanhret A.M., Napadovska L.V., Hudzynsky O.D., Titarenko H. and Korinko M., Melnik Yu.V.), as a process (Pilipenko A.A., Kasich A.O., Tsygan R.M., Karban O.I.), as a complex 
Table 1

\section{Definition of the "accounting and analytical support" concept}

\begin{tabular}{|c|c|}
\hline Author & Definition \\
\hline $\begin{array}{l}\text { Shtanhret A.M., } \\
\text { Karaim M.M. } \\
(2017)\end{array}$ & $\begin{array}{l}\text { Accounting and analytical support is a qualitative informational service of security objects by creating a dynamic system for } \\
\text { the collection of proper, qualitative and relevant data as required in the external and internal environment, their generalization, } \\
\text { systematization, analysis and verification, storage and effective use for making of relevant managerial decisions. }\end{array}$ \\
\hline $\begin{array}{l}\text { Napadovska L.V., } \\
\text { Dobiya M., } \\
\text { Sander Sh., } \\
\text { Matezych R. (2008) }\end{array}$ & $\begin{array}{l}\text { The authors consider the system of accounting and analytical support for a business entity as the summary } \\
\text { information on the state and results of its activity, concentrated in various forms of financial and managerial (internal } \\
\text { economic) accounting. }\end{array}$ \\
\hline $\begin{array}{l}\text { Hudzynsky O.D. } \\
(2008)\end{array}$ & $\begin{array}{l}\text { The accounting and analytical system is an integrated system of methods of accounting and analytical support for } \\
\text { management through the specific internal system and system-wide functions. }\end{array}$ \\
\hline $\begin{array}{l}\text { Titarenko H., } \\
\text { Korinko M. (2010) }\end{array}$ & $\begin{array}{l}\text { Accounting and analytical systems as systems based on accounting data, including operational data and using } \\
\text { statistical, production, reference and other types of information for economic analysis. The accounting and analytical } \\
\text { system is considered to be the collection, processing, and evaluation of all types of information used for managerial } \\
\text { decisions at macro and macro levels. }\end{array}$ \\
\hline Yuzva R.P. (2011) & $\begin{array}{l}\text { Accounting and analytical support is a set of accounting and analytical processes, united in the accounting and } \\
\text { analytical system and aimed at satisfying users' information needs by transforming primary information into } \\
\text { generalized in accordance with the set purposes, as well as regulatory, methodological, organizational, programmatic, } \\
\text { mathematical, technical, and ergonomic support. }\end{array}$ \\
\hline $\begin{array}{l}\text { Parkhomenko O.V. } \\
(2006)\end{array}$ & $\begin{array}{l}\text { Informational and analytical support for the management system is a combination of all information used, specific } \\
\text { means and methods of its analytical processing, and specialists' activity for its effective improvement and use. }\end{array}$ \\
\hline $\begin{array}{l}\text { Bezrodna T.M. } \\
(2010)\end{array}$ & $\begin{array}{l}\text { Accounting and analytical support is a process of preparation of accounting and analytical information, providing } \\
\text { its quantity and quality. The term "support" means execution, ensuring the supplying of accounting and analytical } \\
\text { information for the management system. This concept should include measures on the preparation of accounting and } \\
\text { analytical information, that is, its preparation process. }\end{array}$ \\
\hline $\begin{array}{l}\text { Volska V.V. } \\
(2012)\end{array}$ & $\begin{array}{l}\text { Accounting and analytical support is the process of collection, preparation, and registration of the enterprises' } \\
\text { accounting information depending on the legal accounting system, and the deep information-based analysis with } \\
\text { certain methods and techniques. }\end{array}$ \\
\hline $\begin{array}{l}\text { Ratushina A.P. } \\
(2012)\end{array}$ & $\begin{array}{l}\text { The system consists of three consecutive stages to be passed by the information intended for management personnel: } \\
\text { recording of operations, information verification and data analysis. }\end{array}$ \\
\hline $\begin{array}{l}\text { Kaminska T. } \\
(2002)\end{array}$ & $\begin{array}{l}\text { The concept is the system of collection, processing, generalization, presentation and analysis of financial information, } \\
\text { provision of its quantity and quality for the enterprise's activity, in particular, its management. }\end{array}$ \\
\hline $\begin{array}{l}\text { Holova S.F. } \\
(2003)\end{array}$ & $\begin{array}{l}\text { Accounting and analytical support is a system of collection, processing, generalization, presentation, and analysis of } \\
\text { financial information, provision of its quantity and quality for the enterprise's activity, in particular, its management. }\end{array}$ \\
\hline $\begin{array}{l}\text { Hylmiyarova M.R. } \\
(2012)\end{array}$ & $\begin{array}{l}\text { Accounting and analytical support is a conceptual model consisting of interrelated accounting and analytical } \\
\text { procedures and used to provide the corporation's management with the necessary information. }\end{array}$ \\
\hline $\begin{array}{l}\text { Pilipenko A.A. } \\
(2007)\end{array}$ & $\begin{array}{l}\text { Accounting and analytical support is a process of creating information conditions for the system functioning, } \\
\text { providing the necessary information, including in the searching system, receiving, storing, transmitting, processing } \\
\text { information, database organization. }\end{array}$ \\
\hline $\begin{array}{l}\text { Melnik Yu.V. } \\
(2011)\end{array}$ & $\begin{array}{l}\text { The accounting and analytical system is determined as: "the accounting and analytical system is a system of } \\
\text { accounting of assets, liabilities, capital and business transactions... preparation of data on the relevant areas of the } \\
\text { accounting process to keep financial, tax, statistical accounting; the use of information technologies in the enterprise's } \\
\text { accounting and analytical activity" [4]. }\end{array}$ \\
\hline $\begin{array}{l}\text { Resler M.V. } \\
(2012)\end{array}$ & $\begin{array}{l}\text { "Accounting and analytical support is a component of the management system. It combines accounting and analytical } \\
\text { transactions into one process, allows for operational analysis, continuous process and using these results when } \\
\text { formulating recommendations for making managerial decisions" [13]. }\end{array}$ \\
\hline $\begin{array}{l}\text { Zahorodniy A.H. } \\
(2010)\end{array}$ & $\begin{array}{l}\text { The system of accounting and analytical support for the enterprise is a form of organization of all types of accounting } \\
\text { and analysis, which purpose is to provide the enterprise managers with information for current and strategic } \\
\text { management decisions and control their implementation. }\end{array}$ \\
\hline $\begin{array}{l}\text { Hurenko T.O., } \\
\text { Derevyanko S.I., } \\
\text { Lipova A.C. }(2013)\end{array}$ & $\begin{array}{l}\text { Accounting and analytical support should be considered as a process of preparation of accounting and analytical } \\
\text { information, ensuring its quantity and quality. The concept of accounting and analytical support appears in two ways: } \\
\text { 1) actions related to collection, registration, generalization, preservation, transfer, and analytical processing of } \\
\text { information; 2) providing the management system with the required quantity of the necessary qualitative information. }\end{array}$ \\
\hline $\begin{array}{l}\text { Runcheva N.V. } \\
(2010)\end{array}$ & $\begin{array}{l}\text { "Accounting and analytical support is a process of preparation of accounting and analytical information on the } \\
\text { enterprise's activities, providing its quantity and quality." }\end{array}$ \\
\hline $\begin{array}{l}\text { Kasich A.O., } \\
\text { Tsygan R.M., } \\
\text { Karban O.I. (2013) }\end{array}$ & process of preparation of accounting and analytical information, providing its \\
\hline $\begin{array}{l}\text { Voloshchuk L.O. } \\
\text { (2011) }\end{array}$ & $\begin{array}{l}\text { The "informational-analytical" concept is wider than the "accounting and analytical support" concept. In the } \\
\text { accounting and analytical context, "support" should be considered as a "guarantee of timely formation and transfer } \\
\text { of high-quality accounting and analytical information." Accounting and analytical support system is a sequence of } \\
\text { information transfer from one subsystem to another, and the result is transferred to decision-making [16]. }\end{array}$ \\
\hline $\begin{array}{l}\text { Haluzina S. } \\
\text { M.(2006) }\end{array}$ & $\begin{array}{l}\text { The concept of accounting and analytical information should be considered focusing on an "analytical" component. } \\
\text { The scientist believes that it has two main meanings: on the one hand, analytical information is a part of the } \\
\text { accounting information complex, which is characterized by appropriate analytically since analytical accounting } \\
\text { is a subset of the set of accounting indicators. On the other hand, analytical information is a kind of economic } \\
\text { information obtained from the accounting system as a result of the analytical management function. }\end{array}$ \\
\hline
\end{tabular}


of accounting and analytical processes (Volska V.V., Yuzva R.P., Parkhomenko O.V.) as a conceptual model (Hylmiyarova M.R.) or a sequence of information transfer (Ratushina A.P., Kuzmich I.R.). But most approaches consider accounting and analytical support to be quite isolated from other information resources of the enterprise: - either as a complex of individual elements (mostly accounting and analysis) that completely provide different levels of information management;

- or as a complex of elements to provide certain activity aspects with information (accounting and economic management of competitiveness, economic security, accounting and economic provision of personnel management or accounting and economic provision of innovation process management, etc.).

But, in our opinion, the AAS should be a continuousflow of information aimed at achieving a common purpose to provide all management levels with complete, reliable, relevant information on various aspects of the activity. This is because countering threats and challenges is possible in today's world provided that they have the most complete, reliable, and accurate information to make effective current decisions and predict their impact on the enterprise's activities in the future.

In our opinion, strategic management may be considered as a streaming process in space and time. This perception requires new approaches to information management because the modern strategic management system should be organized by logistics principles.

The logistic approach applied to the AAS provides an optimal sequence of information functions, streamline information flows and operational monitoring and analysis of development indicators.

Many methodological and theoretical approaches to formation and use of information flows at the company are described in the economic literature. The complex of information flow processes at the enterprise forms the information system consisting of: 1) information infrastructure (information and technology); 2 ) information support (means of information collection, processing, storage, and transmission - information and communication resources). An information flow represents one element of the information space, considered from different sides. For example, Oliynychenko O.M. (2012) notes that "the information flow is the circulation of information at the enterprise necessary to develop and implement management decisions." Vasenev K.A. (2003) notes that "Information flows make a complex of messages objectively reflecting the development in business processes." Pisarenko T. (2010) states that the information flow is "a complex of circulating systems between them and relation with the environment needed for the enterprise management and control." According to Verba V.A. (2009), the main components of the information space include information resources, software and hardware, and organizational legal documents and information infrastructure.
The traditional system of the accounting and analytical support combines methods, technologies, and tools of accounting and analysis for management decisions. The AAS structure is built in accordance with one of the two approaches. The first approach involves "bottom-up" organization; its elements of individual objects of the accounting and analysis are combined in the system by communication. The second one involves "top-down" formation of the accounting and analytical system: composition, elements, and communication link accounting and analysis system are determined by the company's ultimate goal (the resulting indicator or indicators). In our opinion, "top-down" building of the accounting and analytical systems is quite effective and convenient, but in addition to communication and information functions, the AAS system should ensure continuity and comprehensiveness of information preparation and analysis in space and time, and provide current, retrospective, and preventive control. That is, various kinds of "input" information should be converted into the enterprise's information system for management decisions but in compliance with new quality requirements for the information support of enterprises required in the modern economic system.

Accordingly, in our opinion, the accounting and analytic support for the enterprise should be considered as a tool for a through polythematic information flow in all management levels, creating links between the elements and providing the information movement from user to user. The information flow, unlike some structural or functional parts of the analytical support for the enterprise, is broader by its purpose and provides not only formation and regulation, but through the law of synergy and systemology concept enhances the overall performance of the enterprise.

Due to the high organization and implementation of key indicators of information flows - direction, structure, operation term - the contours of the AAS structure and relationships can be clearly formed and outlined. Specific features of the enterprise's information flows speed, discretion, intensity, capacity, density, versatilityimprove the quality of information fullness and the AAS effectiveness.

In contrast to the amount of certain structural parts of the enterprise's information support, an information flow is a systemology concept and, according to the law of synergy, is a testament to the high level of organization and, therefore, enhances the overall performance of the company. But at the same time, the information flow distribution into separate information components can detect possible quantitative and qualitative changes in information and the degree of interaction and relationship of the information components. So, the information flow distribution into separate components (of information) reveals probable qualitative and quantitative changes in information, the degree of correlation of information components. 
Thus, the information flow is a managed subsystem that exists in the space of four variables: time, space, quantity, and quality.

The information flow operation time is defined by the period from the start of the information flow to receive by a person (or top-management), who created an information request. The information flow direction from the formation source to the consumer is regulated by time, determined by the management plan terms, current technological standards, need of timely reports and management decisions.

The quality of information flows depends on the information quality. Thus, information flows ensure the enterprise's economic efficiency while providing qualitative characteristics of information - reliability, accuracy, objectivity, relevance, usefulness, relevance, etc.

The effectiveness of strategic management is measured by the reaction to changes in the environment, it means by appropriate time limits of information movement. The information flow speed is determined by the maximum amount of information received for the minimum time period and demonstrates the economic system efficiency and its ability to flexibly, promptly, and adequately respond to changing the internal and external environment. At the same time, the fast information flows are a prerequisite for significant competitive advantages due to fast implementation of innovative ideas.

Effective management of the enterprise depends on how the company managers handle information about the market, conditions for its functioning, the number of competitors, goods - analogues, development dynamics and more. The difficulty is that only limited information sources and amount are available in real time. Consequently, there is always an information asymmetry even in the enterprise - a condition when one of the links has the necessary management information, and the other - does not or not enough. So there is no significant amount of credible analytical information flows. This approach makes it possible to avoid information isolation of each individual link management, data backup, "overproduction" of information, prevents conflicting distorted data in the enterprise's information space, and this, in turn, will reduce the risk of the business.

In our opinion, accounting and analytical support for the enterprise should be:

- strategy-oriented, it means using the approach to information data preparation considering the long-term impact on the enterprise;

- holistic, it means in spite of three management levels and many functional components, the AAS is organized under the logistic principle to create an opportunity for proper communication between all information elements; - organizationally and methodically uniform, it means allowing to apply common principles, instruments, a methodology for information preparation to avoid dual interpretation or significant contradictions of the same data processed by different approaches.

Thus, accounting and analytical support should become one of the key tools to create and maintain the enterprise's information flow while ensuring common processes, methods, and operation principles.

The AAS structure and organization are defined by information types already circulating in the enterprise's system and ultimately required for the formation and implementation of its strategy. The AAS system components should be ordered based on certain principles, which we summarized in Table 2.

The AAS principles, as a part of the information flow, are grouped in an integrated manner by three areas defining the sequence of the AAS construction from the activity strategy formation to the formulation of requirements for information support quality.

However, in the process of the enterprise's strategic management, which does not exclude permanent coordinated tactical and operational management, the key element should be used to provide coordination and evaluation of the efficiency of the entire economic system. In our opinion, the component of the AAS economic security (AASES) has to be such an element. The AASES system is capable of providing real-time information support for the monitoring of security aspects in compliance with strategic decisions in terms of the enterprise's economic security.

Analysing the current economic researches, the conclusion can be made that often issues related to the enterprise's economic security were in the scientists' focus, although the "economic security" (ES) concept is quite new to our economic community. Existing approaches to the term determination may be grouped in several areas:

1) economic security is understood as protection against economic crimes (theft, fraud, falsification, industrial espionage, etc.);

2) economic security is understood as security against internal and external threats;

3) economic security is understood as a state of effective use of resources or capacity. The approach, trying to avoid the use of the threat concept in determining the EES, is based on the economic terms of achieving the enterprise's goal, that is, a resource and functional approach;

4) economic security is understood as the availability of competitive advantages. The approach, which supporters believe that competitive advantages resulting from compliance with material, financial, human, technical, and technological capabilities and the enterprise's organizational structure with its strategic goals and objectives provide a certain level of economic security. But advantages and potential do not guarantee economic security to the company without their use and implementation;

5) economic security is understood as realization and protection of economic interests from internal and external threats, its protection of the enterprise: human resources and intellectual potential, information, technology, capital, and profits. 
Table 2

Principles of accounting and analytical support

\begin{tabular}{|c|c|c|}
\hline General scientific principles & $\begin{array}{l}\text { Special principles of construction } \\
\text { and management of the AAS system }\end{array}$ & $\begin{array}{l}\text { Principles of information formation, } \\
\text { disclosure, and analysis }\end{array}$ \\
\hline Principles: & complexity & caution \\
\hline \multirow{8}{*}{$\begin{array}{l}\text { - consistency } \\
\text { - integration } \\
\text { - compatibility } \\
\text { - standardization and harmonization } \\
\text { - development } \\
\text {-priority } \\
\text { - phased } \\
\text { - balance }\end{array}$} & consistency & sequence \\
\hline & flexibility & continuity \\
\hline & hierarchy & information completeness \\
\hline & transparency & form and content availability \\
\hline & simplicity and reliability & timeliness \\
\hline & rationality & differentiation \\
\hline & stability & substance over form prevalence \\
\hline & unity & economy \\
\hline Principles of operation: & self-regulation & reasonableness \\
\hline \multirow{9}{*}{$\begin{array}{l}\text { - consistency } \\
\text { - reliability } \\
\text { - unity } \\
\text { - accessibility } \\
\text { - relevance }\end{array}$} & efficiency & materiality \\
\hline & & scientific nature \\
\hline & & consistency \\
\hline & & complexity \\
\hline & & specificity \\
\hline & & $\begin{array}{l}\text { unity and consistency of analytical } \\
\text { procedures }\end{array}$ \\
\hline & & objectivity and accuracy \\
\hline & & sufficient information \\
\hline & & information reliability and comparability \\
\hline
\end{tabular}

Source: Summarized by the author

So, these definitions demonstrate that economic security is believed to be an integral part of strategic management. Strategic management, in spite of a wider range of tasks and functions, is focused to achieve positive results in the long-term stable performance, which to some extent is the purpose of the system of the enterprise's economic security. Therefore, an effective combination of all components and expanded tasks and functions in one AAS will improve management efficiency.

Traditionally, the main purpose of accounting and analytical support for economic security is the most complete creation of timely and accurate information for management decisions to prevent (or minimize) external and internal threats.

The system of the enterprise's economic security traditionally includes the following components: a) intellectual and human resources; b) information; c) technical and technological; d) financial; e) legal and political and environmental; f) force. The paper states that "the main purpose of its (ES system) operation is to provide accurate and relevant information for the enterprise's economic management while selecting areas to maintain its security and sustainable development."

The effectiveness of the enterprise's economic security depends mainly on consistency and perfect functioning of management decisions, which implementation is based on external and internal information, developed plans and forecasts for the enterprise. Creation of the sustainable flow of accounting and analytical information in the economic security system is based on certain principles as follows: revealing information needs and the most effective ways to meet them; an objective reflection of the financial and economic activity; unity of information from different sources; timely information; increased reliability coefficient.

However, in our opinion, the analytical and accounting support for economic security for the purpose of strategic management should be considered as a part of the information flow but rather focus on the fact that this element in modern conditions should create conditions for criteria evaluation of management decisions. So, this requires broadening and deepening of the AAS functions and requirements.

Thus, the traditional functions of accounting and analytical support for the enterprise's economic security might define the following:

1) information function that provides information on the level of economic security, the impact of key threats and risks of internal and external security subjects;

2) accounting function that involves recording all the facts of economic activity;

3) control function that allows checking the primary account information, monitor the effectiveness of security subjects;

4) analytical function that allows a retrospective, current, and strategic analysis based on primary accounting information.

However, in our opinion, traditional functions should be supplemented by estimation and control functions to provide the ability to monitor management decisions for compliance with its terms of economic security. 
So, from the standpoint of strategic management, the AASES system should include information on prediction of consequences of management decisions and provide current, retrospective, and preventive control. This approach requires the main areas of the AASES application to be expanded.

1) monitoring of the current and forecasting of the future economic security in general for the company and in terms of the main functional components;

2) analysis, search, and provision of more effective ways to use existing resources;

3) meet the information requests from internal and external security subjects;

4) creation of conditions to account a security aspect while making and implementing management decisions on operational, tactical, and strategic levels;

5) analysis and study of changes in the level of economic security under the influence of challenges, risks, and threats; 6 ) coordination of internal capabilities, the enterprise's interests and the environment's requirements and challenges in order to create conditions for sustainable enterprise development.
Thus, the economic security system as a key AAS element aimed at evaluation and control of the decisions from the view of economic security provides for the following algorithm of actions:

1) development of the necessary and sufficient list of indicators and criteria of the enterprise's economic security, depending on the industry, financial state, and strategic objectives of the enterprise;

2) retrospective analysis of the results and effectiveness of the strategic, tactical and operational decisions within the accounting and analysis subsystem to develop the full information about the degree of effectiveness of the selected actions;

3) formation of control and corrective measures, it means implementation of current and preventive control (Figure 1).

\section{Findings}

The resulting analytical information for the next phase allows comparing and evaluating the planned and forecast indicators of economic security at every

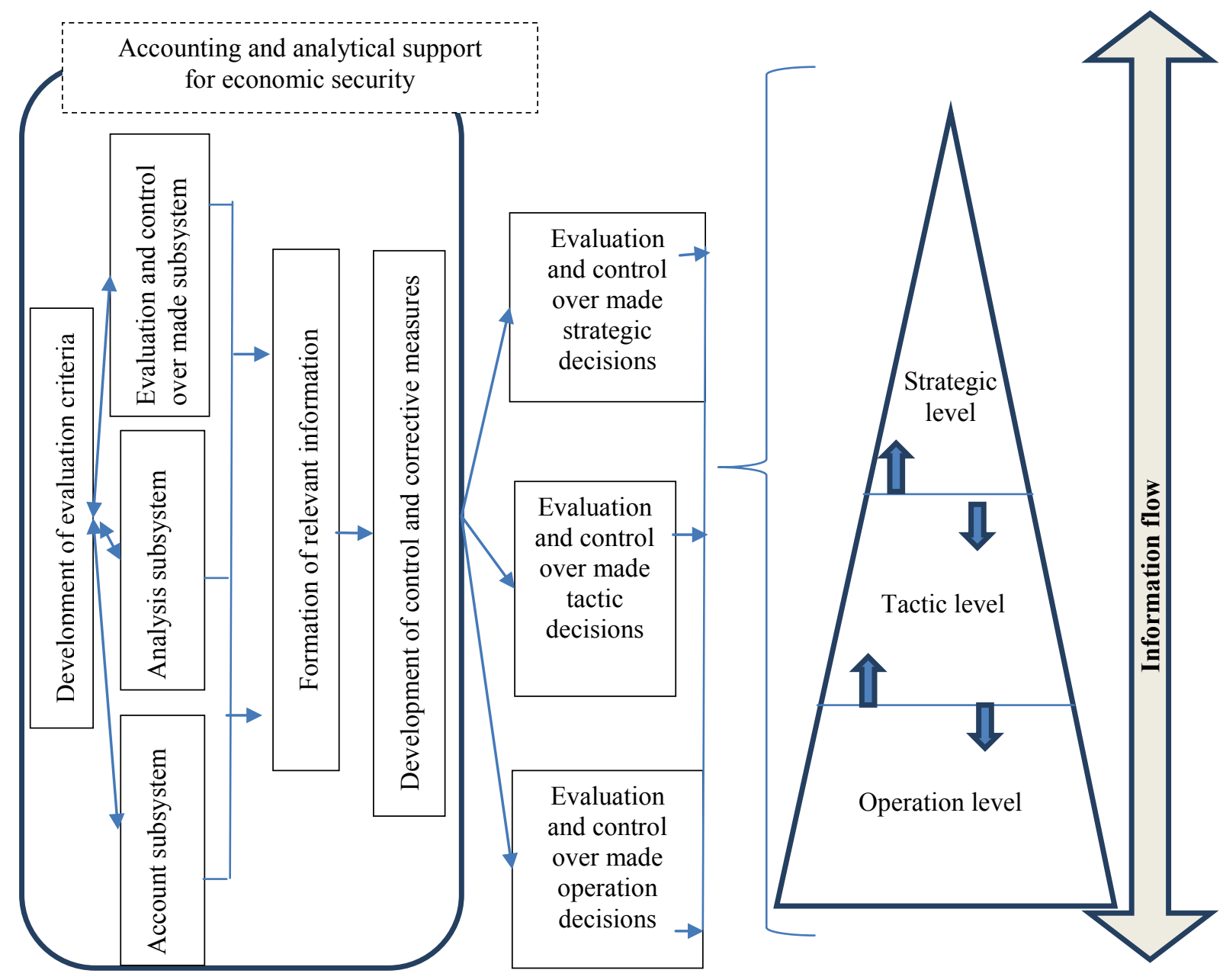

Figure 1. Mechanism of the formation of evaluation and control of the accounting and analytical support for economic security Source: compiled by the authors 
management level. The assessment and monitoring in real time allow the creation of a stable basis for making reasonable decisions.

Issues of theoretical development of the entities' economic security and the characteristic of its individual components are described in many works by such scientists as Kasich A.O. (2013), Zahorodniy A.H. (2010), Melnik Yu.M. (2015), Zhukova D.A. (2015). However, analysis of the scientific publications reveals that certain aspects of the modern development of the theory and methodology to ensure the function of the system of the enterprises' economic security require further consideration. The issue of accounting and analytical support for enterprise management was studied by Kirsanova V.V., Faschenko M.O. (2014), Shtanhret A.M. (2017), Kuzhelny M.V., Linnyk V.G. (2001) et al.

\section{Conclusions}

The management system directly depends on the information scope, quality, and intended use. Traditional methods and tools of information preparation do not adequately meet the requirements of modern management, and hence qualitatively and quantitatively new scope of information is required, as well as their structuring considering the influence of risks and uncertainties of the market environment. Creation of the through-flow system of accounting and analytical support as a key component to ensure financial stability and economic security has to be the key to long-term effective strategic development and management of the company. The effectiveness of the company's strategic management is a complex task mainly dependent on consistency and perfect functioning of the mechanism of collection, accumulation, processing, storage, analysis, and transfer of information and the subsequent mechanism of management decision approval. Currently, many scientific approaches to building the accounting and analytical system are developed and there are many developments related to its component structure, principles, and relationships. However, the main drawback of the existing approaches to forming the system of accounting and analytical support is that mostly the system outline, components, specific methods, and approaches to accounting and analysis are determined, but the system is not seen as a whole dynamic tool to provide a focused development tool (transfer of the enterprise as a control object from one state to another) in a certain time period. Therefore, one of the priorities in development of the enterprise's accounting and analytical system is its construction under the principles and approaches of logistics management, allowing to form the necessary data information array in a single space, providing a unified approach to information preparation and, at the same time, to avoid information isolation of individual management units, duplication and "overproduction," and data misrepresentation. In addition, each system requires formation of feedback provided to some extent by management control functions. In this regard, accounting and analytical support for economic security was proposed to be used as a system to provide assessment and control of the enterprise's strategic development. Due to economic security tools, retrospective, current, and preventive control of decisions should be achieved.

Issues on detailed development of indicators and criteria of economic security require for further fundamental studies for the purpose of effective analysis and control.

\section{References:}

Bezrodna T.N. (2008). Oblikovo-analitychne zabezpechennya upravlinnya pidpryyemstvom: vyznachennya sutnosti ponyattya [Accounting and analytical support for business management: the concept definition] Visn. Sxidnoukrayinskogo nacz. un-tu im. V. Dalya, no. 10 (128), vol. 2, pp. 12-18. Retrieved from: http://dspace.snu.edu.ua:8080/jspui/bitstream/123456789/523/8/bezrodna.pdf (Âccess: 10.04.2018)

Haluzina S.M. (2006). Aspektyi povyisheniya roli uchetno-analiticheskoy informatsii v sisteme upravlennya organizatsiey: monogr [Aspects of increased role of accounting and analytical information in the enterprise's management system: monograph] SPb.: Knowledge. (in Ukrainian)

Hanhal L.S. (2016). Mekhanizm oblikovo-analitychnoho zabezpechennya upravlinnya konkurentospromozhnistyu silskohospodarskykh pidpryyemstv [Mechanism of accounting and analytical supportformanagement of agricultural enterprises'competitiveness]. Innovative Economy, vol. 1-2 [61], pp. 124-130.

HaydukI.S. (2016). Oblikovo-analitychne zabezpechennya upravlinnya ekonomichnoyu bezpekoyu pidpryyemstva [Accounting and analytical support for the enterprise's economic security]. University Economic Bulletin, no. 28/1, pp. 33-40.

Holov S.F. (2003). Upravlinskyy oblik: pidruchnyk [Management accounting: Textbook]. K.: Libra. (in Ukrainian) Hrinka T.I. (2013). Suchasni problemy oblikovo-analitychnoho zabezpechennya v systemi ekonomichnoyi bezpeky pidpryyemstva [Modern problems of accounting and analytical support in the economic security system] Proceedings of Kirovograd National Technical University. Economics, vol. 23, pp. 414-418.

Hudzynsky O.D., Kireytsev H.H., Pakhomova T.M. (2008). Teoretychni aspekty formuvannya oblikovoanalitychnoho mekhanizmu menedzhmentu [Theoretical aspects of formation of the management accounting and analytical mechanism] AIC Accounting and Finance, no. 3, pp. 89-93.

Hurenko T.O., Derevyanko S.I., Lipova A.S. (2013). Teoretychni osnovy formuvannya oblikovo-analitychnoho zabezpechennya upravlinnya [Theoretical principles of formation of accounting and analytical support for management] Retrieved from: http://ecnof_2013_10(3)_35.pdf (Access: 03.03.2018) 
Hylmiyarova M.R. (2012). Kontseptualnaya uchetno-analiticheskaya model denezhnyih potokov korporativnih struktur [Conceptual accounting and analytical model of money flows of corporate structures] Vestnyk Pskovskogo gosudarstvennogo unyversyteta. seryya:ekonomyka.pravo.upravlenye, pp. 44-48. Retrieved from: http://pskgu.ru/ projects/pgu/storage/wt/wet02/wet02_07.pdf (Access: 03.03.2018)

Kaminska T.H. (2002). Oblikovo-analitychnyy protses: yoho zmist stadiyi [Accounting and analytical process: its content]. SAU Scientific collection, vol. 50, pp. 313-31.

Kasich A.O., Tsygan R.M., Karban O.I. (2013). Naukovo-metodychni osnovy oblikovo-analitychnoho zabezpechennya upravlinnya prybutkom pidpryyemstva [Scientific and methodological basis of accounting and analytical support for the enterprise's profit management] Problems of Economics, no. 1, pp. 191-196.

Kirsanova V.V., Faschenko M.O. (2014). Oblikovo-analitychne zabezpechennya yak skladova funktsionuvannya systemy ekonomichnoyi bezpeky pidpryyemstva [Accounting and analytical support as part of the economic security system]. Odessa: V International Scientific and Practical Internet Conference "Problems of markets and regional development in Ukraine in the XXI century".

Kuzhelny M.V., Linnyk V.G. (2001). Teoriya bukhhalterskoho obliku [Theory of Accounting]. K.: KNEU. (in Ukrainian)

Melnik Yu.M. (2015). Oblikovo-analitychna systema v zabezpechenni finansovoyi stiykosti promyslovoho pidpryyemstva $\mathrm{v}$ tsilyakh prohnozuvannya bankrutstva [The accounting and analytical system to ensure the financial stability of an industrial enterprise to predict bankruptcy]. Ekonomika: realiyi chasu, no 3(19), pp. 213-217. Retrieved from: http://economics.opu.ua/files/archive/2015/No3/213-217.pdf(Access: 5.02.2018) Mnikh E.V. (2011). Ekonomichnyy analiz [Economic Analysis: Textbook]. K.: Knowledge. (in Ukrainian)

Napadovska L.V., Dobiya M., Sander Sh., Matezych R. et al. (2008). Teoriya bukhhalterskoho obliku: monohr. [Accounting Theory: monograph.]. K.: KNTU. (in Ukrainian)

Oliynychenko O.M. (2012). Udoskonalennya mekhanizmu orhanizatsiyi informatsiynykh potokiv $\mathrm{u}$ marketynhoviy diyalnosti na pidpryyemstvi [Improvement of the mechanism of organization of information flows in the enterprise's marketing activity [Text] / Scientific papers of the National University of Food Technologies. no. 42, pp. 171-176.

Parkhomenko O.V. (2006). Informatsiyno-analitychne zabezpechennya protsesu pryynyattya rishen $\mathrm{v}$ systemi naukovo-tekhnichnoyi informatsiyi [Information and analytical support for decision-making in the scientific and technical information system] (PhD Thesis). Kyiv: KNEU.

Pisarenko T. (2010). Rol upravlinskoho obliku u formuvanni efektyvnoyi systemy informatsiynykh potokiv na pidpryyemstvi [Role of management accounting in formation of an effective system of information flows at the enterprise [Text] Economic Analysis. vol. 6, pp. 295-297.

Popovich P.Ya. (2008). Ekonomichnyy analiz diyalnosti subyektiv hospodaryuvannya: pidruchnyk [Economic analysis of business activity: textbook]. K.: Knowledge (in Ukrainian)

Pylypenko A.A. (2007). Orhanizatsiya oblikovo-analitychnoho zabezpechennya stratehichnoho rozvytku pidpryyemstva [Organization of accounting and analytical support for the company's strategic development]. Kharkiv: KhNUE. (in Ukrainian)

Ratushyna O.P. (2012). Oblikovo-analitychne zabezpechennya analizu rezultativ diyalnosti [Accounting and analytical support of performance analysis]. AIC Accounting and Finance, no. 1, pp. 72-76.

Resler M.V. (2012). Znachennya oblikovo-analitychnoyi informatsiyi v upravlinni pidpryyemstvom [Value of accounting and analytical information to company management] Scientific Bulletin of the Uzhgorod State University: Economics, vol. 09. Ed.3 (37), pp. 146-148.

Runcheva, N. V. (2011). Oblikovo-analitychne zabezpechennya silskohospodarskoyi diyalnosti [Accounting and analytical support for agricultural activities]. Tavria State Agrotechnical University, vol. 186, pp. 186-192.

Shtanhret A.M. (2017). Oblikovo-analitychne zabezpechennya upravlinnya ekonomichnoyu bezpekoyu pidpryyemstva: metodychni zasady [Accounting and analytical support for management of the enterprise's economic security: methodological foundations]. Economics and business management. Mukachevo State University. No. 9, pp. 722-726. Retrieved from: http://www.economyandsociety.in.ua/journal/9_ukr/123.pdf (Access: 10.01.2018)

Shtanhret A.M., Karaim M.M. (2016). Oblikovo-analitychne zabezpechennya v protsesi upravlinnya ekonomichnoyu bezpekoyu pidpryyemstva [Accounting and analytical support in the management of the enterprise's economic security]. Scientific notes, Vol. 53, pp. 167-172. Retrieved from: http://nz.uad.lviv.ua/static/ media/2-53/20.pdf (Access: 10.01.2018)

Titarenko H.B. (2010). Metodychni pidkhody dlya pobudovy oblikovo-analitychnoyi systemy z vykorystannyam ekspertnykh otsinok [Methodological approaches for building the analytical accounting system using specialists' reviews]. AIC Accounting and Finance, no. 4, pp. 66-69.

Vasenev K.A. (2003). Analiz informatsionnyih potokov promyishlennogo predpriyatiya v kontrollinge [Analysis of information flows of an industrial enterprise in controlling [Text]. Company Management, no. 2, pp. 46-56.

Verba V.A. (2009). Informatsiyne zabezpechennya upravlinnya rozvytkom kompaniyi [Information support for the enterprise's development management [Text]. Formation of market economy: Collection of KNEU, no. 22, pp. $145-154$.

Voloshchuk L.O. (2011). Oblikovo-analitychne zabezpechennya upravlinnya innovatsiynym rozvytkom pidpryyemstva [Accounting and analytical support for the company's innovative development]. Papers by Odessa Polytechnic University: Scientific and industrial collection, vol. 2(36), pp. 301-307. 
Volska V.V. (2012) Metodychni pidkhody do oblikovo-analitychnoho zabezpechennya ta audytu upravlinskoyi diyalnosti ahrarnykh pidpryyemstv [Methodological approaches to accounting and analytical support and agricultural enterprises management audit]. Theory and methodology of accounting, control and analysis, no. 3(24), pp. 83-88.

Yuzva R.P. (2011). Oblikovo-analitychne zabezpechennya upravlinnya diyalnistyu pidpryyemstv spyrtovoyi promyslovosti [Accounting and analytical support management of enterprises in the alcoholic beverages industry] (PhD Thesis). Ternopil: Ternopil Economic University.

Zahorodniy A.H. (2010). Otsinyuvannya efektyvnosti systemy oblikovo-analitychnoho zabezpechennya menedzhmentu pidpryyemstva [Evaluation of effectiveness of accounting and analytical support for the enterprise's management] Proceedings of the International Scientific Conference ["State and prospects of the accounting and information system in Ukraine"] (Ternopil, 23-24 April 2010) / Ministry of Education and Science of Ukraine. Ternopil: TNEU. T. 31-32.

Zhukova D.A. (2015). Metodychnyy pidkhid do vyznachennya yakosti informatsiynykh potokiv na pidpryyemstvi [Methodical approach to determination of the information flow quality at the enterprise]. University's scientific notes, no 2, pp. 308-315. 